\title{
Biogas in the transport sector: Actor and policy analysis focusing on thedemand side in the Stockholm region
}

J onas Ammenberg, Stefan Anderberg, Tomas Lönnqvist, Stefan Grönkvist and Thomas Sandberg

The self-archived postprint version of this journal article is available at Linköping University Institutional Repository (DiVA):

http:/ / urn.kb.se/ resolve?urn=urn:nbn:se:liu:diva-142390

N.B.: When citing this work, cite the original publication.

Ammenberg, J ., Anderberg, S., Lönnqvist, T., Grönkvist, S., Sandberg, T., (2017), Biogas in the transport sector: Actor and policy analysis focusing on thedemand side in the Stockholm region, Resources, Conservation and Recycling, (129), 70-80.

https:// doi.org/ 10.1016/j.resconrec.2017.10.010

Original publication available at:

https:// doi.org/ 10.1016/j.resconrec.2017.10.010

Copyright: Elsevier

http:// www.elsevier.com/

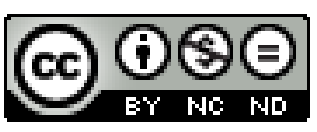




\title{
Biogas in the transport sector
}

\section{- actor and policy analysis focusing on the demand side in the Stockholm region} Jonas Ammenberg*1 ${ }^{1}$, Stefan Anderberg ${ }^{1}$, Tomas Lönnqvist ${ }^{2}$, Stefan Grönkvist ${ }^{2}$ and Thomas Sandberg ${ }^{3}$

*Corresponding author: jonas.ammenberg@liu.se

${ }^{1}$ Linköping University, Department of Management and Engineering, Division of Environmental Technology and Management, SE-581 83 Linköping, Sweden

${ }^{2} \mathrm{KTH}$ - Royal Institute of Technology, Division of Energy Processes, Department of Chemical Engineering and Technology, Teknikringen 42, SE-100 44 Stockholm, Sweden

${ }^{3} \mathrm{KTH}$ - Royal Institute of Technology, Department of Industrial Economics and Management, Lindstedtsvägen 30, SE-100 44 Stockholm, Sweden

\section{Keywords}

biogas, transport, Stockholm, policy instrument, socio-technical system, transition

\begin{abstract}
Sweden has ambitions to phase out fossil fuels and significantly increase the share of biofuels it uses. This article focuses on Stockholm County and biogas, with the aim to increase the knowledge about regional preconditions. Biogas-related actors have been interviewed, focusing on the demand side. Biogas solutions play an essential role, especially regarding bus transports and taxis. Long-term development has created well-functioning socio-technical systems involving collaboration. However, uncertainties about demand and policy cause hesitation and signs of stagnating development.

Public organizations are key actors regarding renewables. For example, Stockholm Public Transport procures biogas matching the production at municipal wastewater treatment plants, the state-owned company Swedavia steers via a queuing system for taxis, and the municipalities have shifted to "environmental cars".

There is a large interest in electric vehicles, which is expected to increase significantly, partially due to suggested national policy support. The future role of biogas will be affected by how such an expansion comes about. There might be a risk of electricity replacing biogas, making it more challenging to reach a fossil-free vehicle fleet. Policy issues strongly influence the development. The environmental car definition is of importance, but its limited focus fails to account for several different types of relevant effects. The dynamic policy landscape with uncertainties about decision makers' views on biogas seems to be one important reason behind the decreased pace of development. A national, long-term strategy is missing. Both the European Union and Sweden have high ambitions regarding a bio-based and circular economy, which should favor biogas solutions.
\end{abstract}




\section{Introduction}

There is an urgent need for a transition towards a more sustainable society (Pachauri et al., 2014; Rockström et al., 2009) involving the replacement of fossil fuels with more sustainable alternatives (e.g. Banerjee et al., 2012). In 2014, the EU's share of energy from renewable sources reached 16\% in gross final use, while the transportation sector was far behind - below $6 \%$ (Eurostat, 2016). For Sweden, the corresponding figures were $52.6 \%$ and $19.2 \%$ (ibid.). However, these figures are accounted for in accordance with the Renewable Energy Directive (RED; European Parliament, 2009), meaning that biofuels based on wastes/by-products are double counted. Measured by energy content, the domestic share of renewables in the transportation sector was 14.7\% in 2014 (Swedish Energy Agency, 2016). Thus, the transportation sector is lagging behind in Sweden as well. However, the government has declared high ambitions regarding transportation and has set a goal of a "fossil-independent" vehicle fleet by 2030 as a step towards achieving $\mathrm{CO}_{2}$ emission neutrality by 2050 (Official Inquiry on Fossil Fuel-Free Road Transportation, 2013). In the beginning of 2017, the government proposed an even further sharpened climate reform, sent to the Council on Legislation (Swedish cabinet office, 2017). If these ambitions are to be realized, several different types of strategies need to be implemented in parallel and without delay, where one important way forward is to significantly increase the use of biofuels of several different types (ibid). This article focuses on a central Swedish region and biogas, which is a biofuel with significant potential (Ammenberg et al., 2017; Dahlgren et al., 2013; Kampman et al., 2016; Lönnqvist et al., 2013), and which until now has been far from realized. Although dealing with national and regional contexts, the study is directed towards challenges of international relevance. Many regions and countries are facing similar challenges and are looking for more sustainable solutions involving biofuels/biogas (Araújo et al., 2017; Banerjee et al., 2012; Christensen and Hobbs, 2016; European Commission, 2010; Eurostat and Savova, 2012; Kampman et al., 2016) ${ }^{1}$.

In Sweden, biogas has been produced from sewage sludge at wastewater treatment plants since the 1930s (Svärd and Jansen, 2003), and sewage sludge is still the single most contributing feedstock (Swedish Energy Agency, 2016). During the 1970-80s, biogas production started within the manufacturing industry and the agricultural sector, and biogas from landfills was collected ${ }^{2}$. From the mid-1990s, co-digestion plants were introduced, producing biogas from different types of feedstock like waste from households, slaughterhouses, catering establishments and food processing industries (Svärd and Jansen, 2003). In 2015, there were 282 biogas plants in Sweden, producing about $1.95 \mathrm{TWh} /$ year in total (of which $187 \mathrm{GWh}$ came from landfills; Swedish Gas Association and Swedish Energy Agency, 2016). About 60\% of the biogas is upgraded and used as vehicle gas (Svensson et al., 2015). Biogas production is much larger in other countries like

\footnotetext{
${ }^{1}$ Several references are included to support the statement, but also to provide examples ranging from global to national/state levels and dealing with a multitude of biofuels. The emphasis is on the EU and biogas.

${ }^{2}$ New legislation has implied that very small amounts of organic material have been landfilled in Sweden since 2005. However, the existing organic material will contribute with gas for many years to come, even if the flows decrease.
} 
Germany, the Netherlands and the UK, but the share of biogas used as a vehicle fuel, i.e. upgraded biogas, is much higher in Sweden (ibid. and Kampman et al., 2016).

The biogas development has resulted in valuable assets in terms of technology and infrastructure (e.g. Lantz, 2013), as well as technological progress regarding production and management of feedstock (Ammenberg et al., 2017); biogas and biofertilizer production (Karlsson et al., 2014); biogas utilization including the development of engines, vehicles, refuelling systems, electricity, and heat production and use (e.g. Fallde and Eklund, 2015); biofertilizer management (Aarsrud et al., 2010; Swedish Waste Management Association, 2012); software, etc. Many actors are involved in the current biogas sector: producers, suppliers, customers, sector organizations, public authorities and academia (cf. Ericsson et al., 2013). Municipalities have played a central role in biogas development in Sweden (Fallde, 2011; Fallde and Eklund, 2015), being owners or partowners of a large share of the existing biogas plants (Eriksson, 2014). Regions (or counties) are essential regarding the demand of renewable solutions including biogas, for example in relation to systems for public transports (Xylia and Silveira, 2017). The biogas sector contributes to local employment (Edwards et al., 2015; Fiksen et al., 2016; Henke and Theuvsen, 2014; Vac et al., 2015) and energy supply, is characterized by knowledge and competence spread over large networks, and has brought new types of interaction as well as the development of new businesses. In addition, the governance of the "biogas sector" has developed, to include regulations, support systems, and practical procedures of different types (Bisaillon and Hellström, 2014; Upham et al., 2016). Taken together, this can be described as the development of a new socio-technical system (Trist, 1981), growing from the niche level in the 1970s towards a more established regime today (Fallde and Eklund, 2015; Geels, 2011). However, from a sociotechnical systems perspective, five decades is a short period of time in comparison with the development of the fossil-based systems since the industrial revolution. Thus, there are probably many opportunities for continued development of the biogas sector, including its technological efficiency and markets.

Particularly during the last 15 years, there has been a significant and stable expansion of the biogas sector, with increasing production and a growing number of gas vehicles - but from a low level. The production increased by about 40\% from 2005 to 2015 (Swedish Gas Association and Swedish Energy Agency, 2016). This development would not have occurred without policy support, and previous studies have indicated a strong link between various policy instruments and biogas development (ibid, Ammenberg and Feiz, 2017; Dahlgren et al., 2013; Hillman and Sandén, 2008; Larsson, 2015; Larsson et al., 2016). From a "theoretical” perspective, biogas production could be increased at least tenfold (Dahlgren et al., 2013) by utilizing a larger share of food waste, agricultural and industrial residues, energy crops and aquatic feedstock. However, Svensson et al. (2015) identify signs of a slowdown, or stagnating development. Many biogas producers appear to face tough challenges, including a struggle to reach or maintain profitability (Ammenberg et al., 2017).

Many studies have evaluated biofuel potential, but these evaluations are often top-down, highly aggregated and focus on long-term perspectives (Banerjee et al., 2012; Beringer et al., 2011; 
Campbell et al., 2008; De Wit and Faaij, 2010; Fischer and Schrattenholzer, 2001; Mendu et al., 2012). These studies can provide valuable inputs on the boundaries of bioenergy solutions, but are not very valuable when developing strategies on the national or local level. Kautto and Peck (2012) emphasize the need to consider ground-level conditions to be able to establish realistic plans on the national level. Similarly, Bagliani et al. (2010) argue that the adoption of renewable energy sources requires careful consideration at the local level. How the biogas solutions can and should be arranged, however, varies between different places and sectors.

\subsection{Aim}

The main aim of this article is to increase knowledge about the regional preconditions for biogas solutions in Sweden. It is based on a study on Stockholm County (see Figure 1), where biogasrelated actors in the region have been interviewed, focusing on the demand side. It complements a study by Lönnqvist et al.(2017), which is based on the same project but directed towards the supply and distribution side. Here, we try to develop an understanding of the socio-technical system by investigating the different actors, their roles and relationships, and their views on the current situation and possible future developments of the biogas sector. A particular ambition is to clarify how different organizations related to the biogas sector look upon relevant policy instruments and to learn more about their views on future policy.
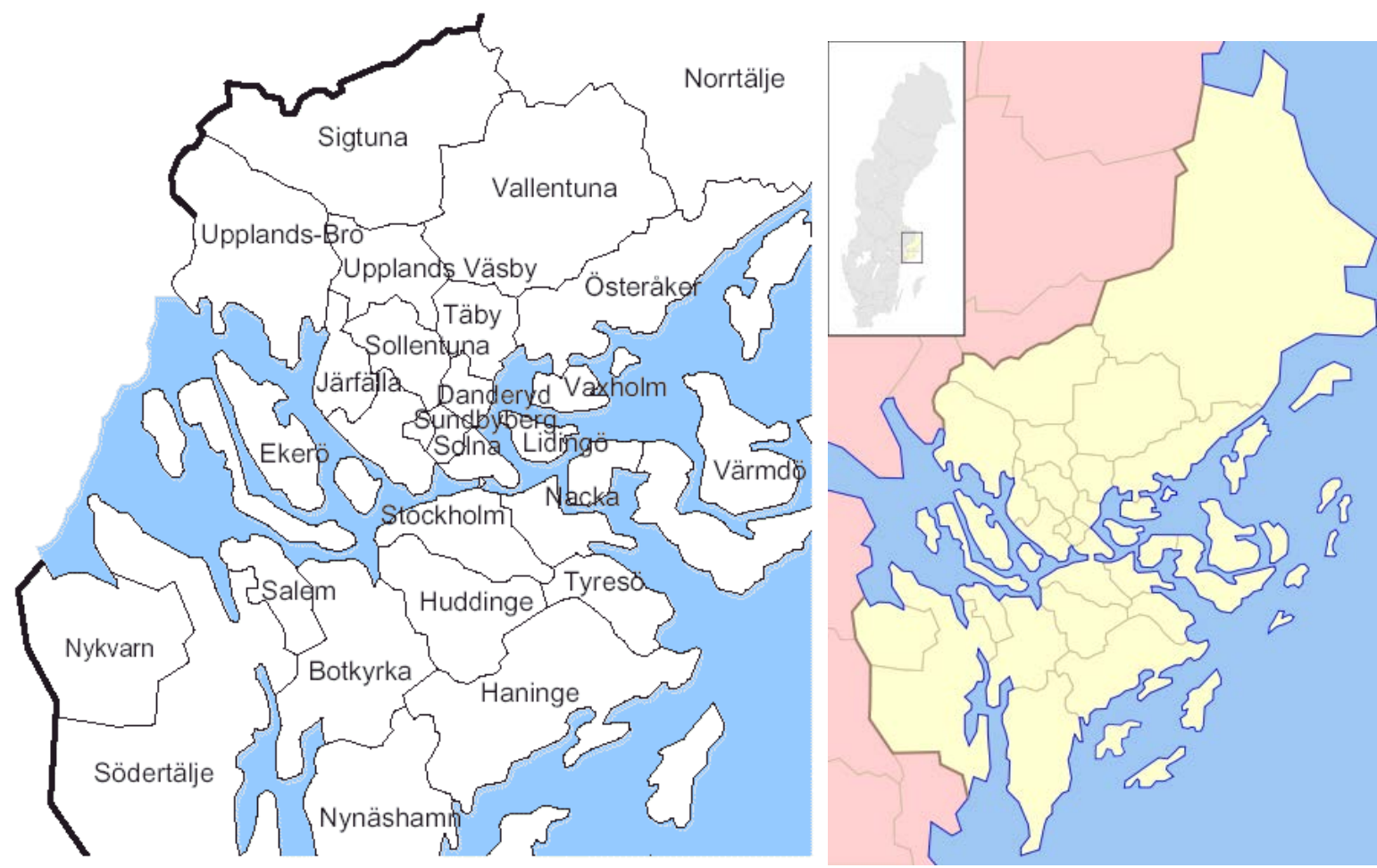

Figure 1. The left part of the figure shows Stockholm County and its 26 municipalities, while the right part shows the county's location in Sweden, on the east coast by the Baltic Sea. 


\section{Methodology}

\subsection{The studied area}

This study has been set up to complement studies at the national and global levels. By focusing on a limited region, we are able to analyse local actors and conditions with a bottom-up perspective. Stockholm County covers 26 municipalities of different sizes, including Stockholm, the Swedish capital. With about 2.3 million inhabitants (Statistics Sweden, 2016), corresponding to almost $25 \%$ of the national population, Stockholm County is the most densely populated area in Sweden. Transportation has been pointed out as one of the major challenges of the region in relation to its environmental/sustainable city and regional development ambitions (Norell Bergendahl, 2016; cf. Fenton and Gustafsson, 2015). For a long time, there has been the intention to provide transport solutions with good environmental and health performance - both on the national level and on the county and local levels. In the Stockholm region, the public bus transports have in recent decades transformed from mainly fossil to $100 \%$ renewable fuels, comprising several different types of renewables including a significant share of biogas (Stockholm County Council., 2017). Today, there are also several other types of vehicles that use renewable fuels, e.g. trucks and cars, and these are owned by public organizations, companies and private persons. Consequently, there are both public and private actors in this region with knowledge and experience regarding fossil and renewable fuels, including biogas. Their experiences regarding biogas in relation to other alternatives and the factors influencing the development are useful to learn from. The region is manageable in size to study, considering the relevant actors involved with the bottom-up approach applied.

\subsection{Selection of participating organizations and respondents}

Initially, organizations of relevance were mapped to cover the supply, distribution and demand/use of biogas in the county. They were categorized according to their roles, and 18 of them were contacted to check if they were willing to participate and to determine which employees to involve, considering their areas of competence. The selection of participating organizations was made to cover essential organizations of different types, as seen in Figure 2. Further explanations, including additional information about the participating organizations and the respondents, are presented in Table 1. It should be noted that several of the involved organizations have a relatively specific role within a certain part of the biogas value chain, for example as a public transport company. However, some of them are involved in several parts of the value chain: the municipalities influence waste management/supply, production, distribution and use, and the operations of E.ON also cover a large part of the value chain. The two largest municipalities (of the 26 in the county) and one mid-sized municipality in terms of population participated. One of the smaller municipalities was also approached with the intention to get information from those with differing conditions, but it chose not to participate. Also observe that some of the participating companies are owned by municipalities. 


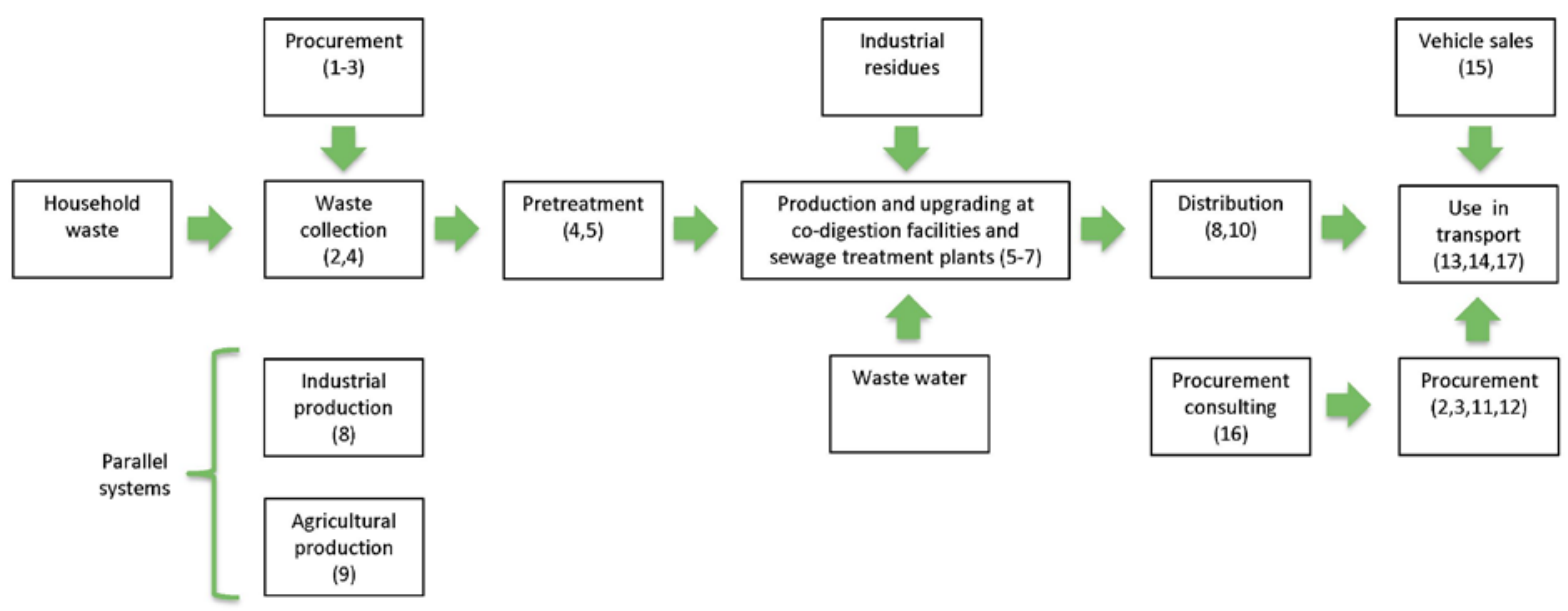

Figure 2. Illustration of the biogas value chain, indicating the position of the organizations involved in the study. It should be observed that some of them have roles in several parts.

Table 1. Organizations involved in the study, their roles and information about respondents. This article focuses on organizations that are primarily demand oriented, but also to some extent on distribution. Some of the names that are translated are not official, while the official Swedish names are written within brackets.

\begin{tabular}{|c|c|c|}
\hline & Supply & \\
\hline & Organization $^{3}$ & Description, including respondents \\
\hline 1 & $\begin{array}{l}\text { Stockholm Water } \\
\text { (Stockholm Vatten) }\end{array}$ & $\begin{array}{l}\text { Municipal company dealing with waste management and water treatment in Stockholm } \\
\text { Municipality, as well as water treatment in Huddinge Municipality. One interview conducted } \\
\text { regarding waste management and procurement in Stockholm Municipality ( } 932000 \\
\text { inhabitants), and one interview regarding the sewage treatment and biogas production plant } \\
\text { in Henriksdal. Respondents: Head of unit, planning and development, waste management; } \\
\text { Head of unit, water treatment. }\end{array}$ \\
\hline 2 & Huddinge Municipality & $\begin{array}{l}\text { Municipality south of Stockholm with } 107000 \text { citizens, making it second largest in the } \\
\text { county. Area: about } 140 \mathrm{~km} 2 \text {. About } 6000 \text { employees and circa } 170 \text { vehicles. } \\
\text { Huddinge Municipality is partial owner of the waste management company SRV (4). } \\
\text { The interview concerned both waste management and transportation. } \\
\text { Respondent: Environmental strategist. }\end{array}$ \\
\hline 3 & $\begin{array}{l}\text { Lidingö } \\
\text { Municipality }\end{array}$ & $\begin{array}{l}\text { Municipality north of Stockholm with } 47000 \text { citizens, making it mid-sized when comparing } \\
\text { the number of citizens with the other municipalities in the county. Area: about } 31 \mathrm{~km}^{2} \text {. } \\
\text { About } 2500 \text { employees and circa } 120 \text { vehicles. } \\
\text { Interview regarding waste management and procurement. } \\
\text { Respondent: Environment and waste developer. }\end{array}$ \\
\hline 4 & $\begin{array}{l}\text { SRV Recycling } \\
\text { (SRV Återvinning) }\end{array}$ & $\begin{array}{l}\text { Waste management company owned by five municipalities. SRV is partial owner of a } \\
\text { pretreatment facility in Sofielund together with Scandinavian Biogas (5). The pretreatment } \\
\text { facility produces slurry for biogas production. Two interviews were performed: one } \\
\text { regarding waste separation and collection, and one regarding SRV's participation in the } \\
\text { pretreatment facility. Respondents: Transport manager; Business unit director. }\end{array}$ \\
\hline 5 & $\begin{array}{l}\text { Scandinavian } \\
\text { Biogas }\end{array}$ & $\begin{array}{l}\text { Biogas producer; designing and operating biogas plants. This company operates three plants } \\
\text { in Sweden, all within Stockholm County, and thus is a part of this study. Two are situated at }\end{array}$ \\
\hline
\end{tabular}

${ }^{3}$ The English versions within brackets are not always official English names of the organization, but rather translations to facilitate the understanding. 


\begin{tabular}{|c|c|c|}
\hline & & $\begin{array}{l}\text { municipal wastewater treatment plants (Henriksdal, Bromma), mainly producing biogas from } \\
\text { sludge. The third (Sofielund) is situated in Huddinge municipality, mainly producing biogas } \\
\text { from food waste. There, the pretreatment facility is co-owned with SRV Recycling, also } \\
\text { participating in the study (4). A fourth plant operates in Ulsan, South Korea. Respondent: } \\
\text { the R\&D director. }\end{array}$ \\
\hline 6 & $\begin{array}{l}\text { The Southwest Stockholm } \\
\text { region Water Works } \\
\text { Corporation } \\
\text { (Sydvästra } \\
\text { Stockholmsregionens va- } \\
\text { verksaktiebolag, SYVAB) }\end{array}$ & $\begin{array}{l}\text { Municipal water treatment company owned by three municipalities and two municipal } \\
\text { companies, located in the south of Stockholm County. Receives external organic material } \\
\text { and co-digests this together with sewage sludge. Most of the produced biogas is upgraded. } \\
\text { Gas distribution by external partners. Respondents: CFO; Quality engineer. }\end{array}$ \\
\hline 7 & E.ON & $\begin{array}{l}\text { International energy company active in electricity, heat, and gas sectors. Produces, } \\
\text { distributes, and sells vehicle gas mainly in urban areas of southern Sweden. Two interviews. } \\
\text { Respondents: Project leader biogas; Head of marketing and vehicle gas sales. }\end{array}$ \\
\hline 8 & Forest industry group & $\begin{array}{l}\text { Forest industry group that manufactures paperboard, paper and wood products and also } \\
\text { runs forestry and produces energy. Interview regarding plans to produce biogas at a paper } \\
\text { mill. Respondent: Project leader new business development. }\end{array}$ \\
\hline 9 & $\begin{array}{l}\text { The Federation of Swedish } \\
\text { Farmers, Östergötland } \\
\text { county } \\
\text { (LRF Östergötland) }\end{array}$ & $\begin{array}{l}\text { Regional branch of the Federation of Swedish Farmers - an agricultural interest } \\
\text { organization. Interview regarding possibilities for and perception of biogas among Swedish } \\
\text { farmers. Respondent: Regional manager. }\end{array}$ \\
\hline & Distribution & \\
\hline 7 & E.ON & See 7 above. \\
\hline \multirow[t]{2}{*}{10} & $\begin{array}{l}\text { Gas Grid Stockholm } \\
\text { ( Gasnätet Stockholm AB) }\end{array}$ & $\begin{array}{l}\text { Regional gas distribution company. Owner of gas grid, responsible for maintenance and } \\
\text { short-term balance of two grids (vehicle gas and cooking gas). Respondent: Grid marketing } \\
\text { manager. }\end{array}$ \\
\hline & Demand, use & \\
\hline 11 & $\begin{array}{l}\text { Clean Vehicles in } \\
\text { Stockholm } \\
\text { (Miljöbilar i Stockholm) }\end{array}$ & $\begin{array}{l}\text { Stockholm municipality is the largest in Stockholm County, with } 935000 \text { inhabitants. Area: } \\
190 \mathrm{~km}^{2} \text {. About } 40000 \text { employees and } 800 \text { vehicles. Clean Vehicles in Stockholm is a part of } \\
\text { Stockholm municipality's environmental administration, with about } 10 \text { employees. The task } \\
\text { is to increase the number of environmental vehicles in the city (excluding buses and subway } \\
\text { - see SL, 17). This mainly includes vehicles used within the municipal operations, but to } \\
\text { some extent incorporates sector organizations, companies and citizens. This organization } \\
\text { also works with improved access to renewable fuels and other issues of relevance. } \\
\text { Respondent: project leader with long-term experience and special expertise regarding heavy- } \\
\text { duty vehicles. }\end{array}$ \\
\hline 2 & Huddinge Municipality & See 2 above \\
\hline 3 & Lidingö Municipality & $\begin{array}{l}\text { See } 3 \text { above. } \\
\text { Interview regarding transportation. } \\
\text { Respondent: Project leader vehicles. }\end{array}$ \\
\hline 12 & $\begin{array}{l}\text { Stockholm Public Transport } \\
\text { (Storstockholms } \\
\text { Lokaltrafik, SL) }\end{array}$ & $\begin{array}{l}\text { SL is a brand for public transport in Stockholm County. Stockholm County Council } \\
\text { procures transport services from private operators, e.g. Keolis (13), under this brand. Public } \\
\text { transport includes both road transport (busses) and rail transport (mainly metro and } \\
\text { commuter trains). Has long-term experience regarding renewable transportation, at least } \\
\text { from the late 1980s, involving ethanol, biogas, RME, electricity incl. hybrids, and HVO. } \\
\text { Respondents: Section manager, sustainable development; Strategist, transport fuels and } \\
\text { energy, sustainable development. }\end{array}$ \\
\hline 13 & Keolis & $\begin{array}{l}\text { One of Europe's largest public transport companies, active in several Swedish regions with } 6 \\
000 \text { employees. Works with busses and rail traffic and also provides automatic metro } \\
\text { systems. Keolis is contracted by SL to operate gas busses, but also busses that run on other } \\
\text { renewables. Keolis has received several consecutive contracts from SL (12). Respondent: } \\
\text { Business area manager. }\end{array}$ \\
\hline 14 & Taxi Stockholm & $\begin{array}{l}\text { Regional business association of about } 900 \text { taxi owners providing taxi services, including } \\
\text { many different types of vehicles, models and fuels (and electricity). All in all, about } 1600\end{array}$ \\
\hline
\end{tabular}




\begin{tabular}{|c|c|c|}
\hline & & $\begin{array}{l}\text { vehicles of which } 1100 \text { are gas vehicles. } \\
\text { Respondent: quality and sustainability controller. }\end{array}$ \\
\hline 15 & Volkswagen Stockholm & $\begin{array}{l}\text { A regional vehicle sales organization within the large Volkswagen group. The group has } \\
\text { extensive experience regarding the production and sales of vehicles, including a variety of } \\
\text { different fuels and electricity. The employees at Volkswagen Stockholm interact with a large } \\
\text { number of customers. } \\
\text { Respondent: fleet sales manager. }\end{array}$ \\
\hline 16 & $\begin{array}{l}\text { Ynnor Consultancy } \\
\text { (Ynnor Konsult) }\end{array}$ & $\begin{array}{l}\text { A small consultancy firm specialised in providing consultancy services, education and } \\
\text { information to companies and other organizations regarding cars, including biogas vehicles. } \\
\text { Involved in the procurement of about } 15000 \text { vehicles per year. Respondent: chief executive } \\
\text { officer. }\end{array}$ \\
\hline 17 & $\begin{array}{l}\text { Widriksson Haulage } \\
\text { (Widrikssons åkeri) }\end{array}$ & $\begin{array}{l}\text { Haulage contractor company with a regional focus and an expressed environmental profile. } \\
\text { They have about } 120 \text { trucks in total: } 60 \text { light trucks of which } 85 \% \text { are driven on biogas, and } \\
60 \text { heavy trucks of which } 42 \% \text { are driven on RME. This company has invested in a refuelling } \\
\text { station and gas storage to obtain } 100 \% \text { biogas as vehicle fuel. Target to be fossil-free by } \\
2020 \text {. In 2006, all vehicles were using diesel fuel - this company has long-term experience } \\
\text { with fossil fuels and know-how regarding a transformation towards renewable transport } \\
\text { solutions. Respondents: Owner, operations manager and communicator. }\end{array}$ \\
\hline
\end{tabular}

\subsection{Interviews}

The interviews were conducted during 2015 and 2016, and lasted between 1 and 3 hours each. Each participating organization was represented by one or a few respondents (see Table 1). The interviews were semi-structured to steer towards the focus of the study, but also to provide room for each respondent to elaborate on issues they found essential. The interviews were conducted by four researchers - some of them in co-operation to ensure that the interviews were conducted in a similar way. In addition, common interview guides were developed in co-operation in order to agree on essential questions to focus on for each of the groups of suppliers, distributors, and users. Before each interview, these guides were adapted to the specific organization. Focusing on the demand (and distribution) side, the following bullets indicate the direction of the questions:

- The role of the organization and the respondent

- Experiences regarding transportation over time - historical overview focusing on renewable alternatives

- Biogas in relation to other alternatives (fossil, ethanol, biodiesel, electricity, etc.); challenges and opportunities

- Use of renewable alternatives internally and, when relevant, any influence on choices made by other actors (for example, municipalities' influence on citizens)

- Biogas in relation to natural gas

- Business/economic implications related to biogas and other alternatives

- The present situation and future development

- The relevance of policy instruments; how these have, are and can influence the development regarding biogas and other alternatives. Any specific suggestions for future policy instruments.

- For those with operations in other parts of Sweden and/or internationally, to clarify if anything of relevance is specific for Stockholm County (or Sweden), and in that case 
reflect upon differences considering other regions in Sweden (or international experiences).

All interviews were recorded, most of them fully transcribed before analysis. For some interviews, summaries were written instead of full transcriptions.

\section{Results}

\subsection{The role of the public sector}

The public organizations, namely the county represented by SL (Stockholm Public Transport) and the three municipalities, have several important roles influencing the development of the transport systems. They all mentioned political objectives, ranging from the national to the local level, as influential for them. Further on, public procurements seem to be key processes that significantly affect how transport services are constructed.

Regarding public bus transports, SL has a very central role within the whole county by e.g. requiring renewable solutions in its procurement procedures, where the operators can choose what type of technology they prefer. However, a specific amount is dedicated to biogas, as SL procures an amount of biogas that matches the biogas production of two relatively large municipal wastewater treatment plants in the county ${ }^{4}$. The demand for the biogas produced within the public sector is thus ensured, and this gas is used to fuel about 330 buses $(15 \%$ of the 2200 buses in total) that are operated by the transport service providers that SL contracts. The annual volume of biogas has grown from about 11.1 to $12.8 \mathrm{MNm}^{3}$ from year 2014 to 2015, and is expected to reach $15 \mathrm{MNm}^{3}$ in 2017. Long-term contracts $(8+2+2$ years) are ideal for the bus operators, as 12 years almost matches the depreciation time for buses.

The municipalities use different types of vehicles, mostly cars but also light trucks. Stockholm municipality is a much larger organization (Table 1) and has many more vehicles than the other municipalities. This organization has to deal with the traffic situation and emissions in the capital's most central areas. Stockholm municipality has come far in replacing fossil fuel vehicles with other alternatives. Its internal organization, Clean Vehicles in Stockholm, has long-term experience regarding these issues and has actively contributed to the changed vehicle fleet. Almost $100 \%$ of the vehicles were stated to fulfil the national "environmental car" requirements 5 , but because some of them are efficient diesel vehicles and petrol is used in dual-fuel cars, $70 \%$ of the fuel used is renewable. Huddinge and Lidingö municipalities have not come as far; even though they have policies and recommendations for vehicles, the share of environmental cars is lower. Huddinge reported a $42 \%$ share of environmental cars, and Lidingö 58\%. The employees at Huddinge municipality use a significant share of fossil fuels in the dual-fuel vehicles, resulting

\footnotetext{
${ }^{4}$ Henriksdal and Käppala waste-water treatment plants.

${ }^{5}$ Referring to the national requirements due from the year 2013 and onwards, deciding if a vehicle is exempted from tax. The type of fuel and the vehicle weight in relation to its $\mathrm{CO}_{2}$ emissions (tail pipe, not well-to-wheel) dedide if a certain vehicle is an 'environmental car' or not. This means that heavier vehicles can have higher emissions while still being approved.
} 
in a low share of renewable fuels $(20 \%)$. However, during the last few years, Huddinge has intensified the work with the ambition to increase the share of environmental cars and use of renewable fuels. Despite the higher environmental car share, Lidingö seemed less ambitious and with a focus on the cheapest way to reach internal objectives regarding vehicles, not striving to come any further. Lidingö is also smaller than the other municipalities, which the respondent argued made it more feasible for employees to use public transport or bicycles for their trips, and short transportation distances means relatively low fuel costs for the municipality.

All respondents from the municipalities indicated that the functions the vehicles are supposed to provide influence the choices. Electrical vehicles were viewed as an option for shorter distances, biogas or ethanol driven vehicles for longer ones. But the interviewed environmental officers stressed that they only provide recommendations, and the actual decisions are taken by the different units of the municipalities. All found it hard to steer their own organizations, and were considering how they can influence in the most effective way. Huddinge uses very few biogasfueled vehicles, and the respondent stated that they are to be replaced by other types. This development was seen as undesirable, because the interviewee found biogas to be a favorable option that should be supported, partially because the municipality has made investments in biogas pretreatment facilities and other types of infrastructure for biogas. Huddinge municipality has contributed to the establishment of refueling stations for biogas together with seven other municipalities in the southern parts of the county. The mentioned reasons for choosing other alternatives included internal skepticism and fear of accidents, which the respondent viewed as consequences of a low level of knowledge. In Lidingö, there is no biogas refueling station, and therefore the municipality has no biogas vehicles. The respondent did not think that the municipality should engage in this matter.

All the interviewed municipalities use electric vehicles, and such vehicles were described as favorable or interesting by the interviewees. Stockholm appeared to focus a lot on electric vehicles and Clean Vehicles in Stockholm expressed that they view electric cars as the best option, at least within the central parts of the city.

All three municipalities have activities directed towards their citizens to influence their choices of transport solutions, but the respondents view it as more challenging to influence the citizens than the municipal organizations.

\subsection{Infrastructure and technology}

Town gas has a long history in Stockholm, where a gas grid was established in the late $19^{\text {th }}$ century. The gas was initially produced from pyrolysis of coal, which later was changed to steam reforming of naphtha. Currently, natural gas combined with biogas makes up the town gas that is used by households, restaurants and local enterprises. The town gas grid covers the central and some other parts of the city of Stockholm, but the area only makes up a small part of the county. The later developed grid for vehicle gas is more relevant for the transport sector. This grid has been expanded in a stepwise manner and includes pipes, depots and some refueling stations. It is owned and operated by Gas Grid Stockholm. This company distributed 203 GWh of gas in 2015, 
including both the town gas and vehicle gas. Of this amount, $127 \mathrm{GWh}$ was distributed as vehicle gas to public refueling stations and refueling stations dedicated to busses in public transport, corresponding to about 34\% of the vehicle gas use in the region (Statistics Sweden, 2017). In addition, SL owns two pipelines stretching between the wastewater treatment plants and depots, with a yearly distribution of about $75 \mathrm{GWh}$ of biogas. Trucks are also used to transport vehicle gas, which apart from biogas also consists of natural gas that represents about $30 \%$ of the total amount.

According to several of the respondents, limited access to vehicle gas was initially an essential problem in the Stockholm region, including too few refueling stations and a shortage of gas at the existing ones. However, some interviewees stated that the access is now sufficient in several parts of the county, even if there still are some areas with very limited access to refueling stations. Widriksson Haulage invested in a refueling station and equipment for mobile storage, due to the mentioned problems. The respondent from Lidingö municipality stated that the long history with limited access to refueling stations and insecure supply has led to a bad reputation for biogas as a vehicle fuel, and still hinders biogas expansion. Volkswagen and Ynnor, with experiences from many parts of the country, emphasized infrastructural aspects as one of the main obstacles for the development of biogas in transport, and pointed out the very limited access to vehicle gas in the northern half of Sweden as a factor that makes it difficult to use biogas vehicles there.

The respondents were asked if and how the natural gas content of the vehicle gas affects them and other actors of relevance. A majority described natural gas as an important enabler and backup solution, but stressed that the share of biogas should be kept high. Several respondents mentioned that most users or potential customers had a low level of knowledge, and therefore did not really know the difference between biogas and natural gas. On the contrary, some of the interviewees found the "natural gas issue" to be central, and stated, for example, that:

- the higher share of biogas, the better environmental declarations

- they only wanted to use $100 \%$ biogas, and

- natural gas soils the reputation of biogas

Several of the respondents mentioned that a challenge for biogas-driven vehicles has been their efficiency, but they were convinced that this is improving and referred to new types of engines with an efficiency similar to diesel engines. Almost all respondents commented on issues related to vehicles, ranging from very general comments to very specific issues. For example:

- E.ON and Taxi Stockholm expressed a need for a wider variety of biogas-driven vehicles to better fulfil the customer needs and expectations. Taxi Stockholm was worried about the opposite development, with fewer models and a lower number of vehicles to choose from. A specific concern seems to be a potential lack of relatively large cars, liked by taxi drivers and their customers, and seen as suitable company cars.

- Widriksson Haulage has made a significant transformation during ten years: from $100 \%$ diesel to a significant share of renewable fuels (biogas + RME). In addition, they have implemented other improvements such as environmentally friendly containers and 
studless tires. Their trucks driven on biogas have slightly shorter service intervals, which is a disadvantage.

- Keolis described the current technology development as rapid, even very rapid for electric vehicles. In relation to this, it was emphasized that large and long-term contracts (via public procurements) are essential so that they can continue to play a role in technology development (e.g., of gas-fueled vehicles), striving towards improved efficiency in cooperation with suppliers.

- Ynnor described plug-in hybrids as an interesting future alternative, but stated that it can be a gas-electric combo, referring to models developed by Saab.

- Taxi Stockholm stated that customers will probably expand their focus to also include $\mathrm{NO}_{\mathrm{x}}$ and particles. After they compared different car manufacturers and models that use the same type of fuel, they claimed that the performance varies significantly regarding $\mathrm{NO}_{\mathrm{x}}$ and particles.

Keolis is operating buses from several different manufacturers that run on different types of fuels, which is challenging. To achieve efficient management, they have chosen only to have vehicles from one supplier and one type of fuel at each depot. This has facilitated efficient operation and service of its buses.

When asked about the future development and role of biogas, several of the large actors (E.ON, Keolis, and Clean Vehicles in Stockholm) expressed that electric solutions would be favorable in the city center, but that biogas would be a complement in the surrounding areas and urban fringe, as well as for long-distance buses, heavy-duty vehicles, and working machines. The respondent from Clean Vehicles in Stockholm stressed that transports of low-value goods (gravel, stone, soil, waste, etc.) is an area where gas-driven trucks can be a favorable option. Biodiesel (FAME) was also mentioned as a good choice for longer distances, and $\mathrm{HVO}^{6}$ was mentioned by several as a fuel with good performance, but limited raw materials (slaughterhouse waste) was viewed as an essential barrier for expansion. Liquid biogas (LBG) was mentioned by several respondents as a feasible way forward. Clean Vehicles in Stockholm found a number of advantages with LBG, and suggested investments in production and transportation of LBG, and to equip refueling stations with possibilities to provide biogas in both liquid and gas form.

\subsection{Knowledge, information and behaviour}

The actors that sell vehicle gas, cars or taxi services described a situation with a low level of knowledge concerning biogas among the customers. The different customer groups lacked knowledge about the possibilities to use biogas and essential differences between different types of technologies and fuels, according to these interviewed actors. The municipalities observed similar challenges regarding the units ordering and using vehicles in their organizations, as well as scepticism and, according to the interviewees, an unfounded fear of accidents. This was also the case for electric cars, but some had experienced a more positive attitude towards these vehicles.

\footnotetext{
${ }^{6}$ Hydrotreated Vegetable Oils (or Hydrogenated Vegetable Oils).
} 
Clean Vehicles in Stockholm stated that old habits influence the behavior (for example, the use of petrol in dual-fuel vehicles), as some of their employees are used to refueling at a specific station and use a certain fuel. Ynnor claimed that it was common to choose dual-fuel vehicles to get the subsidies, but then to mainly use petrol.

According to an absolute majority of the interviewees, the national environmental car requirements greatly influence the choice of vehicles when a "green alternative" is preferred. This standard is currently based on vehicle weight and tailpipe $\mathrm{CO}_{2}$ emissions (a heavier vehicle is allowed to emit more). The answers indicate that it may be common that the user/owner does not know more than that some requirements are fulfilled and, for example, regards a relatively large diesel vehicle as a good environmental choice. In general, in the process to decide on transport solutions by companies and units within public organizations, there seems to be a very limited focus on the broad range of positive synergy effects that can be linked to biogas solutions (cf. Hagman and Eklund, 2016; Fiksen et al., 2016). This was acknowledged by several actors, who recognised a need to communicate more about biogas solutions and thereby increase the level of knowledge - and as a result the demand for these solutions as well.

\subsection{Market conditions and economic viability}

The large international energy company E.ON has long played a significant role in the development of the biogas sector in Stockholm County and some other parts of the country. The respondent from E.ON described a long period of growth, but where the limited demand has forced the company to focus on building the market stepwise in Sweden: first go to market and sell biogas, and via contracts create a basis; then supply gas bought locally or secure a non-local supply and establish fueling stations; and finally, if possible, establish their own production and expand the supply. However, the relatively steady development towards reasonable profit was now stated to have shifted to "abeyance" - a more passive mode to see what will happen. Volkswagen also reported a slowdown regarding the sale of biogas vehicles, and it pointed out that the development resembles what happened with bioethanol some years ago. This company has conducted a customer survey involving the 500 largest customers in Stockholm, Gothenburg and Malmö ${ }^{7}$. Its customers clearly regard environmental performance as important, but find economic issues most paramount. In line with these findings, the interviews clearly revealed that economic considerations play a major role in the choice of vehicles, especially when biogas vehicles (and other renewable options with similar characteristics) are compared with vehicles fueled by fossil fuels. The lower second-hand value of gas vehicles was often emphasized as an important factor influencing what types of vehicles companies choose to lease, or what types a consultancy firm such as Ynnor recommends. Volkswagen also pointed out that the great customer interest in diesel influences the market in terms of what models the company develops and demonstrates. These answers indicate that economic considerations often focus on vehicle costs without taking into account issues such as effects on image/branding. In this regard the representatives for Widriksson Haulage seemed to have a broader perspective. They argued that a

${ }^{7}$ The three cities in Sweden with the largest number of citizens. 
strengthened environmental profile contributes to improved profit, and viewed the extra costs related to the investment in renewable technology as marketing costs.

However, the trend with increased use of electric cars contradicts the conclusion that economic considerations are decisive, as many of the organizations prioritize electric vehicles although they are aware that they can be significantly more expensive. None of the respondents brought up the second-hand value of the electric vehicles, but one acknowledged that there are many uncertainties regarding the life cycle costs of electric vehicles, for example, costs for disassembly and battery handling - concluding that it might be an expensive option. However, one of the municipality representatives stated that electric vehicles were good from an economic perspective because they could charge them without any extra costs, as the costs for electricity were included in the rents of the buildings where the cars were charged. These buildings, however, were owned by a municipally owned real estate company, i.e. another part of the "same" organization.

Taxi Stockholm uses about 1600 vehicles, of which almost $70 \%$ are gas vehicles. However, the share of gas cars has recently decreased while the share of diesel cars has increased. As taxis are replaced every third year, a transformation of the fleet may be rapid. This taxi organization has many very small member companies that when deciding about vehicle investments are making choices to get favorable owner conditions, but also to fulfil customer requirements and needs. Examples of very essential customer requirements for the development are:

- Taxi Stockholm, referring to Swedavia's ${ }^{8}$ system/requirements regarding taxi transports from/to airports, but also requirements from other clients.

- Widriksson Haulage has gone through a major transformation towards renewable solutions, mainly due to requirements from a very large customer. Widriksson Haulage has chosen 100\% biogas supplied from Scandinavian Biogas (its Södertörn plant), due to requirements regarding traceability. This alternative results in traceability to source.

- Ynnor stated that biogas is recommended to, or prioritized by, some customers, e.g. suppliers of services to municipalities or county councils with environmental requirements, or those that have a connection to the production of biogas (e.g. feedstock supplier).

- Volkswagen reported that biogas is favoured by customers that are really eco-aware, with an expressed and strict environmental or corporate social responsibilities profile. A majority of these organizations are found within the public sector.

Taxi Stockholm stated that the dynamic situation, for example with unstable policies, makes it difficult to choose between different options. It would prefer a more stable gas price, not linked

\footnotetext{
${ }^{8}$ Swedavia is a state-owned company that owns, operates and develops Sweden's national basic infrastructure of airports, including Arlanda and Bromma airports in Stockholm County. At Arlanda aiport, Swedavia only allows taxis fulfinging the national environmental car requirements. Further on, the time of queing is shortened for vehicles with low $\mathrm{CO}_{2}$ emissions, which has been an important driver for choosing biogas within the taxi sector.
} 
to petroleum ${ }^{9}$. The respondent from Clean Vehicles in Stockholm also mentioned the locked price in relation to petroleum, and stated that it is a big mistake for the biogas business as the lower price levels cause losses within a sector with no or small margins. Instead, the interviewee argued for development towards a market where the customers sometimes pay a bit more (than for petrol) to get the superior environmental performance associated with biogas.

Several of the respondents stressed that it is very problematic that petrol and diesel-fueled vehicles are chosen to such a large extent, and sometimes even are considered as environmental cars in accordance with the national regulations. E.ON emphasized that fossil fuels do not have to pay for all their costs, while biogas is not fully rewarded for the values created by this fuel. Lidingö municipality was considering some kind of internal bonus-malus ${ }^{10}$ system, meaning that those buying cars with worse environmental performance would have to support those investing in cars with better performance.

\subsection{Policy instruments}

All respondents found policy to be very influential regarding transport solutions and choices of vehicles/fuels, not least regarding biogas. In particular, actors representing the county or municipalities, together with Keolis hired by public organizations, stated that the national ambitions and environmental objectives (e.g. regarding climate change) have a significant impact on their organizations regarding transportation. Several described the national long-term ambitions as being clear for many years, e.g. to phase out fossil fuels, but indicated that there is a lack of a national strategy for how to get there within the set time frames (i.e. 2030 or 2050). Some rules for public procurement were perceived to limit the possibilities to provide long-term conditions or require vehicles/fuels that were regarded as the best from an environmental perspective. Huddinge stated that more effective policy instruments to support biogas solutions on the national level are needed, and this was supported by comments from several other interviewees. Clean Vehicles in Stockholm mentioned the possibility to use local regulations to transform the transport systems.

An absolute majority of the involved actors described the biofuel policy landscape as very dynamic and uncertain, which they perceived as problematic. For example, the respondents mentioned new and significantly amended regulations within Sweden and the EU that make it difficult to know what vehicles and fuels to choose, as the conditions can change significantly during their lifetime. Tax exemptions were perceived as essential from an economic standpoint, but also mentioned as an example of short planning horizons. Several respondents mentioned that late in 2015, it was still not clear if the tax exemptions were going to remain in $2016^{11}$. The

\footnotetext{
${ }^{9}$ Commonly, the biogas distributors adjust the price of biogas in relation to the price of petroleum, so that biogas should be regarded competitive from an economic standpoint by customers.

${ }^{10}$ Latin terms for good (bonus) and bad (malus). The bonus-malus system was suggested in a governmental inquiry 2013 (Official Inquiry on Fossil Fuel-Free Road Transportation, 2013), with the purpose that high polluting alternatives to some extent are to fund transport solutions with a superior environmental performance. It has been one of the policy instruments proposed and reproposed after modifications by the Swedish Government.

11 The decision that the tax exemptions were to be granted until 2020 came late in 2015.
} 
economic policy instruments, such as investment support, tax exemptions, and exemptions from congestion and parking fees, influence the economy for many actors on the supply ${ }^{12}$, distribution and demand side in several ways. Policy changes can relatively rapidly influence the demand. SL exemplified this by referring to the reduced use of RME/FAME as a response to increased taxation (in 2015). Clean Vehicles in Stockholm stated that the decision in 2015 to grant tax exemptions for biogas from 2016 to 2020 was important, for example, as it influenced the rapid introduction of new gas trucks.

The series of interviews manifested that the national environmental car requirements play a major role regarding choices of vehicles, for example, by being commonly referred to in public procurements of vehicles and transport services. The municipalities of Stockholm and Malmö have established a web page ${ }^{13}$ that can be used to find vehicles fulfilling these requirements - a page that is frequently used, according to Clean Vehicles in Stockholm. The respondents saw essential drawbacks related to the environmental car definition, exemplified by statements indicating that:

- It incorporates a very limited environmental scope, focusing on tailpipe $\mathrm{CO}_{2}$ emissions. A large share of the environmental advantages with biogas solutions are excluded by such a definition. It was mentioned that biogas solutions contribute to decreased $\mathrm{NO}_{\mathrm{x}}$ and noise levels, as well as nutrient recycling (circular economy).

- In practice, these regulations have led to a large share of diesel vehicles, i.e. not towards a fossil-free transport sector.

- We are facing serious environmental challenges and our future development depends heavily on policy instruments, so the requirements should be tougher.

- The definition has been frequently changed, thereby undermining investments with a long-term perspective.

Clean Vehicles in Stockholm pointed out that it has considered the possibilities to introduce an environmental car definition that covers additional environmental impact categories, and also mentioned ongoing work in co-operation with the Swedish Transport Association on a definition for trucks. Such a definition was also requested by a few other respondents.

All of the actors were asked about future policy instruments, both regarding what they expected and what they preferred. Looking ahead, several of the respondents were critical to the suggested new bonus-malus system. They did not criticize the basic concept, which is simply that highpolluting alternatives are to some extent to fund transport solutions with a superior performance, but argued that biogas vehicles/solutions should be supported, i.e. not be seen as neutral or malus as some preliminary suggestions have indicated ${ }^{14}$. Some comments were more general,

\footnotetext{
12 See Lönnqvist et al. 2017.

${ }^{13}$ www.miljofordon.se.

${ }^{14}$ According to a memorandum from the Swedish Government, the bonus-malus proposal has been modified after the interviews were conducted. In March 2017, it was suggested that biogas vehicles get a premium (i.e., are seen as bonus), but a significantly smaller premium than electric vehicles (Government offices of Sweden, 2017).
} 
arguing for the strong support of all renewable alternatives. One of the interviewees said that there could have been a large scale use of ethanol in Sweden, but is not due to limited support on the national level. Several of the actors mentioned the risk of a similar development for biogas.

Volkswagen and Ynnor pointed out that the policy focus is on new vehicles (e.g. investment support or reduced taxes for a few years), and thought it should also include the second-hand market. Otherwise, a significant focus is on short periods, for example a leasing period of three years for new cars. Longer time perspectives would give stronger incentives and a faster transition towards renewable alternatives, making environmental cars more attractive on the second-hand market. Both these actors emphasized the importance of understanding how customers/users make their choices, where some types of support might be good for the employee using a vehicle (e.g. providing reduced value of fringe benefits), while others are more relevant for the employer/owner. These respondents also emphasized the importance of designing policy instruments that address the relatively low second-hand value of the gas vehicles in comparison with the diesel vehicles they compete with. The respondent from Volkswagen suggested a combination involving investment leverages and operation aids, while Ynnor stated that road taxes adapted to the total amount of emissions would increase the incentives to use biogas vehicles, thereby improving their second-hand value. Regarding future development of renewable fuels, several respondents mentioned EU regulations as problematic, especially the indirect land use change (iLUC) regulations. These were viewed as unmotivated and significantly hindering for parts of the Swedish biofuel development. Arguments concerned that Sweden has a lot of fallow agricultural land, and that this land could be used for energy crop cultivation.

\section{Concluding discussion}

The interviews resulted in a great deal of relevant information. To a large extent, the selected respondents on the supply ${ }^{15}$, distribution and demand sides provided a similar picture, and there appears to be a consensus regarding many central issues influencing the development for biogas solutions.

Biogas solutions play a significant role in the Stockholm region, especially in the public transport and taxi sectors. There are established socio-technical systems providing transport services of different kinds, and the respondents described long-term development towards improved services and efficiency, as well as ongoing advances in several areas. From a feedstock potential standpoint, the amount of biogas could increase significantly within the region (Lönnqvist et al., 2017, 2015), and this potential may be needed to reach the national objectives of a fossil-fuel independent vehicle fleet by 2030 and $\mathrm{CO}_{2}$ emission neutrality for Sweden by 2050. However, some of the expansion and development for biogas seems to have slowed down. The last years' uncertainties about policy and the future demand for biogas seem to be important reasons results in line with those presented by Fenton and Kanda (2016), studying Basel, Switzerland, and Odense, Denmark. They also found institutional challenges that act as a barrier for

${ }^{15}$ See Lönnqvist et al. (2017). 
biofuel/biogas development. It appears that some influential actors are awaiting the coming "rules of the game" and signals from central customers before deciding about future steps.

Public organizations are central actors in the development of biogas and other renewables within the transport sector (Fallde and Eklund, 2015; Fenton and Kanda, 2016). Via public procurements, SL ensures that fossil fuels are phased out successively from the public transports and guarantees that there is a demand for the biogas produced at municipal wastewater treatment plants in the county. This approach means that several regional and municipal interests are addressed in parallel, and it is an example of a broader and more collaborative approach that contrasts silo mentality (de Paiva Duarte, 2015; cf. Senge et al., 2005), where each unit handles its own matters in isolation. This is not only about optimizing transport services or cutting fossil use; by linking socio-technical systems, it also involves efficient water and waste management, and nutrient recycling in the biogas case, and is about systems integration to reach further (Vernay et al., 2013). Another public organization was mentioned as very influential in relation to cars, namely Swedavia, which operates the two larger airports in the county. The requirements and queuing systems for taxis at these airports that promote gas-fuelled taxis have strongly contributed to a transformation of the taxi fleet in a renewable direction, involving a relatively large number of biogas vehicles. The three municipalities provided a mixed picture. Stockholm has come very far regarding the share of "environmental cars", and its organisation Clean Vehicles in Stockholm seems to be very engaged and competent. Huddinge and Lidingö clearly work with these issues, but are lagging behind Stockholm and expressed lower ambitions (cf. Fenton and Gustafsson, 2015). In Sweden, public organizations can be expected to be forerunners and to work extensively with renewable solutions. However, a challenge for the municipal environmental strategic organizations involved is that they recommend vehicles, but the actual decisions are taken by others (managers within other parts of the organisations).

This study shows a large and widespread interest in electric vehicles. This indicates that the number of buses and cars fuelled by electricity is likely to increase. The future role of biogas will partly be decided by how such an expansion comes about. Arguments regarding energy efficiency, and reduced levels of noise and exhaust emissions, seem to make electric buses a favoured alternative in city centre areas (cf. Borén et al., 2017) ${ }^{16}$. From a local environmental standpoint, it may thus be rational to increase the share of electric vehicles in inner Stockholm. However, for the national targets about a transport sector that is independent of fossil fuels, the effect is less certain. Several respondents saw a risk that electricity will replace biogas, as decision makers often tend to favour one particular alternative (some referred to a previous shift from ethanol to biogas). Nevertheless, the public inquiry about a fossil-free vehicle fleet (Official Inquiry on Fossil Fuel-Free Road Transportation, 2013) indicates a need for the biogas sector to expand further, in parallel with the expansion of other renewables, including renewable electricity. The large and more experienced organizations (such as SL, Keolis, E.ON, and Clean Vehicles in Stockholm) in Stockholm County emphasized the importance of a mix of different

\footnotetext{
${ }^{16}$ Assuming that they represent a significant share of the total transports (and adherent problems) in these areas.
} 
renewable options, and suggested to use biogas for public transports in the outer city and urban fringe, long-distance buses, heavy duty vehicles and working machines. However, an essential challenge to solve before a large-scale implementation of electric alternatives is how to open up new user groups for biogas. Otherwise, there may be a risk of a transition where electric buses and cars replace biogas solutions, instead of complementing them (Fenton and Kanda, 2016). Such developments could prevent the biogas sector from further expansion and risk the investments in this socio-technical system and its development from a niche to an established regime (cf. Fallde and Eklund, 2015; Geels, 2011; Nykvist and Nilsson, 2015). Stockholm County is large enough for several different types of solutions, but for smaller regions/cities (in Sweden and other countries), it may be even more important to consider if and how existing biogas systems shall be complemented.

Several respondents compared different transport solutions, and argued for or against certain alternatives. Naturally, economic issues are influential and were mentioned by many; for example, the lower second-hand value of gas vehicles was mentioned in comparison to diesel cars. However, it cannot be taken for granted that the second-hand value of diesel cars will remain high. The logic seems to be different regarding electric vehicles, as they are commonly more expensive to buy ${ }^{17}$ and the second-hand value and other costs (for battery handling, etc.) are very uncertain, but still there is a great interest for them among the respondents/actors. These results are in line with findings from the Netherlands (Bakker et al., 2014), investigating stakeholders' views on electric vehicles.

The answers showed that there are essential challenges in comparing different types of transport solutions, for example regarding their efficiency and environmental performance. Further on, the scope can be very different, ranging from energy for propelling a certain type of vehicle to broader considerations including the whole system (infrastructure, etc.) and a multitude of factors. In addition, the comparisons seem to be based on different types of values - old, existing or expected future values - where the transport sector seems to use many test values with significantly underestimated impacts (Fontaras et al., 2017; Kadijk et al., 2015). Finally, there appears to be many uncertainties involved, not least regarding the costs for the potential new electric solutions. For informed decision-making, it is essential to handle these uncertainties in a strategic way (Feiz, 2016). Regarding efficiency, it should be noticed that the studied systems are large socio-technical systems, meaning that they are relatively slow developing systems (Geels and Schot, 2010). The biogas solutions have become more efficient, but if such systems are frequently replaced by other types of systems, they will not reach more mature/efficient levels (Fallde and Eklund, 2015).

This study further revealed that policy issues are viewed as very central and influential, and many respondents declared that policy instruments strongly influence the development regarding biofuels including biogas. The "environmental car" definition and the financial support that it will

\footnotetext{
${ }^{17}$ However, there are in some cases subsidies or investment aids that will decrease the difference.
} 
bring about has been a powerful instrument, but the definition has shifted and at times it has left room for vehicles with relatively bad climate performance, and even encompassed cars driven on fossil fuels. The focus on tailpipe $\mathrm{CO}_{2}$ emissions in the definition means that the scope is very limited and does not cover what should be included in a broad environmental systems analysis of transport solutions. As biogas solutions may involve several different types of positive synergy effects (Ammenberg and Feiz, 2017; Hagman and Eklund, 2016), such regulations can be seen as most unjust for them, assuming that the purpose is to choose transport solutions with a good environmental performance (or societal resource efficiency) when a life-cycle perspective is applied. Several respondents expressed a need to increase the level of knowledge about biogas solutions to get an improved understanding among decision-makers and customers regarding the broad positive socio-economic effects, and to be able to make better comparisons with other alternatives. The very dynamic policy landscape with great uncertainties about decision makers' view on biogas seems to be one important reason behind the decreased pace of development. A clear national long-term strategy is missing, but would be essential to indicate how the farreaching national visions/objectives about reduced dependence on fossil fuels and climate change mitigation should be materialized, combined with policy instruments to support such a development, to be able to move from strategic, via tactical, to more operational actions (cf. Upham et al., 2016). Olsson et al. (2015), studying Stockholm's road transport system combining policy analysis and backcasting, describe it as imperative to immediately change the policy with the purpose to strengthen the development of renewable alternatives. In addition to programs to reduce negative environmental impact, both the European Union and Sweden have high ambitions and visions regarding a bio-based and circular economy (European Commission, 2012; FORMAS, 2012; cf. de Besi and McCormick, 2015), which should favor biogas solutions as they to a large extent are both bio-based and circular by, for example, transforming waste flows into fuels and recycling nutrients. Even so, a large share of the actors within the biogas sector in Stockholm County appears to be very frustrated, as the fossil-based alternatives are commonly prioritized and profitable to apply in the society, despite being heavily polluting, not bio-based and not part of a circular economy.

\section{Acknowledgements}

This study has been funded by the f3 Centre (Fossil Free Fuels), in turn funded by the Swedish Energy Agency and industrial partners. The authors would like to thank the participants and Dr. Linda Olsson, energy and climate strategist at Finspång Municipality, for her contribution. Linda has conducted several interviews, and transcribed and summarized them.

\section{References}

Aarsrud, P., Bisaillon, M., Hellström, H., Henriksson, G., Jakobsson, E., Jarlsvik, T., Martinsson, U., Jensen, C., Johansson, L.G., Kanerot, M., 2010. Förädling av rötrest från storskaliga biogasanläggningar. Waste Refinery Rapport-20.

Ammenberg, J., Feiz, R., 2017. Assessment of Feedstock for Biogas Production, Part II: Results for Strategic Decision Making. Resources, Conservation \& Recycling. doi:10.1016/j.resconrec.2017.01.020 
Ammenberg, J., Feiz, R., Bohn, I., 2017. Systematic assessment of feedstock for an expanded biogas production - A multi-criteria approach (No. BRC 2017:1). Biogas Research Center (BRC), Linköping.

Araújo, K., Mahajan, D., Kerr, R., Silva, M. da, 2017. Global Biofuels at the Crossroads: An Overview of Technical, Policy, and Investment Complexities in the Sustainability of Biofuel Development. Agriculture 7, 32. doi:10.3390/agriculture7040032

Bagliani, M., Dansero, E., Puttilli, M., 2010. Territory and energy sustainability: the challenge of renewable energy sources. Journal of Environmental Planning and Management 53, 457 472.

Bakker, S., Maat, K., van Wee, B., 2014. Stakeholders interests, expectations, and strategies regarding the development and implementation of electric vehicles: The case of the Netherlands. Transportation Research Part A: Policy and Practice 66, 52-64. doi:10.1016/j.tra.2014.04.018

Banerjee, R., Benson, S.M., Bouille, D.H., Brew-Hammond, A., Cherp, A., Coelho, S.T., Emberson, L., Figueroa, M.J. na, Grubler, A., Jaccard, M., Ribeiro, S.K., Karekezi, S., He, K., Larson, E.D., Li, Z., McDade, S., Mytelka, L.K., Pachauri, S., Patwardhan, A., 2012. Global Energy Assessment (No. ISBN 9780521182935 paperback). Cambridge University Press, Cambridge UK and New York, NY, USA and the International Institute for Applied Systems Analysis, Laxenburg, Austria, Cambridge.

Beringer, T.I.M., Lucht, W., Schaphoff, S., 2011. Bioenergy production potential of global biomass plantations under environmental and agricultural constraints. Gcb Bioenergy 3, 299-312.

Bisaillon, M., Hellström, H., 2014. Styrmedel för biogasproduktion (No. U2014:02). Avfall Sverige-utveckling, Malmö.

Borén, S., Nurhadi, L., Ny, H., Robèrt, K.-H., Broman, G., Trygg, L., 2017. A strategic approach to sustainable transport system development - Part 2: the case of a vision for electric vehicle systems in southeast Sweden. Journal of Cleaner Production, Systematic Leadership towards Sustainability 140, 62-71. doi:10.1016/j.jclepro.2016.02.055

Campbell, J.E., Lobell, D.B., Genova, R.C., Field, C.B., 2008. The global potential of bioenergy on abandoned agriculture lands. Environmental science \& technology 42, 5791-5794.

Christensen, A., Hobbs, B., 2016. A model of state and federal biofuel policy: Feasibility assessment of the California Low Carbon Fuel Standard. Applied Energy 169, 799-812. doi:10.1016/j.apenergy.2016.01.121

Dahlgren, S., Liljeblad, A., Cerruto, J., Nohlgren, I., Starberg, K., 2013. Realiserbar biogaspotential i sverige år 2030 genom rötning och förgasning, Rapport B2013:02. Avfall Sverige.

de Besi, M., McCormick, K., 2015. Towards a Bioeconomy in Europe: National, Regional and Industrial Strategies. Sustainability 7, 10461-10478. doi:10.3390/su70810461

de Paiva Duarte, F., 2015. Barriers to Sustainability: An Exploratory Study on Perspectives from Brazilian Organizations. Sust. Dev. 23, 425-434. doi:10.1002/sd.1603

De Wit, M., Faaij, A., 2010. European biomass resource potential and costs. Biomass and Bioenergy 34, 188-202. 
Edwards, J., Othman, M., Burn, S., 2015. A review of policy drivers and barriers for the use of anaerobic digestion in Europe, the United States and Australia. Renewable and Sustainable Energy Reviews 52, 815-828. doi:10.1016/j.rser.2015.07.112

Ericsson, K., Nikoleris, A., Nilsson, L.J., 2013. The biogas value chains in the Swedish region of Skåne (Environmental and Energy System Studies No. Report 89). Department of Technology and Society Environmental and Energy Systems Studies, Lund University, Lund, Sweden.

Eriksson, O., 2014. Municipalities are crucial. Government May 2014, 68-69.

European Commission, 2012. Innovating for Sustainable Growth: A Bioeconomy for Europe. $\operatorname{COM}(2012) 60$ final.

European Commission, 2010. A strategy for smart, sustainable and inclusive growth. Communication from the Commission Europe 2020. COM(2010) 2020.

European Parliament, 2009. Directive on the promotion of the use of energy from renewable sources and amending and subsequently repealing Directives 2001/77/EC and 2003/30/EC, Official Journal of the European Union.

Eurostat, 2016. Renewable energy statistics - Statistics Explained [WWW Document]. URL http://ec.europa.eu/eurostat/statisticsexplained/index.php/Renewable_energy_statistics\#Transport (accessed 9.21.16).

Eurostat, Savova, I., 2012. Europe 2020 Strategy - towards a smarter, greener and more inclusive EU economy? (No. ISSN 1977-0316 Catalogue number: KS-SF-12-039-EN-N). European Union, Luxembourg, Belgium.

Fallde, M., 2011. Miljö i tanken?: Policyprocesser vid övergången till alternativa drivmedel i kollektivtrafiken i Linköping och Helsingborg 1976-2005.

Fallde, M., Eklund, M., 2015. Towards a sustainable socio-technical system of biogas for transport: the case of the city of Linköping in Sweden. Journal of Cleaner Production 98, $17-28$.

Feiz, R., 2016. Systems Analysis for Eco-Industrial Development: Applied on Cement and Biogas Production Systems (PhD Thesis). Linköping University, Linköping, Sweden.

Fenton, P., Gustafsson, S., 2015. Contesting sustainability in urban transport-perspectives from a Swedish town, in: Natural Resources Forum. Wiley Online Library, pp. 15-26.

Fenton, P., Kanda, W., 2016. Barriers to the diffusion of renewable energy: Studies of biogas for transport in two European cities. Environmental Planning and Management. doi 10, 1176557.

Fiksen, K., Harsem, S., Lossius, T., Magnus, E., 2016. Verdiskaping fra produksjon av biogass på Østlandet. THEMA Consulting Group AS.

Fischer, G., Schrattenholzer, L., 2001. Global bioenergy potentials through 2050. Biomass and Bioenergy 20, 151-159. doi:10.1016/S0961-9534(00)00074-X

Fontaras, G., Zacharof, N.-G., Ciuffo, B., 2017. Fuel consumption and CO2 emissions from passenger cars in Europe - Laboratory versus real-world emissions. Progress in Energy and Combustion Science 60, 97-131. doi:10.1016/j.pecs.2016.12.004

FORMAS, 2012. Swedish Research and Innovation Strategy for a Bio-based Economy (No. Report: R3:2012). Swedish Research and Innovation, Stockholm, Sweden. 
Geels, F.W., 2011. The multi-level perspective on sustainability transitions: Responses to seven criticisms. Environmental Innovation and Societal Transitions 1, 24-40. doi:10.1016/j.eist.2011.02.002

Geels, F.W., Schot, J., 2010. The dynamics of transitions: a socio-technical perspective, in: Grin, John, Rotmans, Jan, Schot, Johan (Eds.), Transitions to Sustainable Development: New Directions in the Study of Long Term Transformative Change. Routledge, pp. 11-104.

Government offices of Sweden, 2017. Bonus-malus system for new vehicles [WWW Document]. Government offices of Sweden. URL http://www.government.se/pressreleases/2017/03/bonusmalus-system-for-new-vehicles/ (accessed 5.24.17).

Hagman, L., Eklund, M., 2016. The role of biogas solutions in the circular and bio-based economy (No. BRC Report 2016). Biogas Research Center (BRC), Linköping University, Linköping, Sweden.

Henke, S., Theuvsen, L., 2014. Social Life Cycle Assessment: Socioeconomic Evaluation of Biogas Plants and Short Rotation Coppices. Proceedings in Food System Dynamics 373383.

Hillman, K.M., Sandén, B.A., 2008. Exploring technology paths: The development of alternative transport fuels in Sweden 2007-2020. Technological Forecasting and Social Change 75, 1279-1302. doi:10.1016/j.techfore.2008.01.003

Kadijk, G., van Mensch, P., Spreen, J., 2015. Detailed investigations and real-world emission performance of Euro 6 diesel passenger cars (No. TNO 2015 R10702). TNO, Delft, Netherlands.

Kampman, B., Leguijt, C., Scholten, T., Tallat-Kelpsaite, J., Brückmann, R., Maroulis, G., Lesschen, J.P., Meesters, K., Sikirica, N., Elbersen, B., 2016. Optimal use of biogas from waste streams. An assessment of the potential of biogas from digestion in the EU beyond 2020. European Commission.

Karlsson, A., Björn, A., Sepehr, S.Y., Svensson, B., 2014. Improvement of the Biogas Production Process: Explorative project (EP1) (Biogas Research Center (BRC) Report No. Report 2014:2). Biogas Research Center (BRC), Linköping University, Sweden, Linköping, Sweden.

Kautto, N., Peck, P., 2012. Regional biomass planning-Helping to realise national renewable energy goals? Renewable energy 46, 23-30.

Lantz, M., 2013. Biogas in Sweden - Opportunities and challanges from a system perspective. Diss., Lund university (PhD Thesis). Lund University, Lund, Sweden.

Larsson, M., 2015. The role of methane and hydrogen in a fossil-free Swedish transport sector (PhD Thesis). KTH Royal Institute of Technology, Stockholm, Sweden.

Larsson, M., Grönkvist, S., Alvfors, P., 2016. Upgraded biogas for transport in Sweden-effects of policy instruments on production, infrastructure deployment and vehicle sales. Journal of Cleaner Production 112, 3774-3784.

Lönnqvist, T., Anderberg, S., Ammenberg, J., Sandberg, T., Dahlgren, S., 2017. Stimulating biogas in the transport sector- an actor and policy analysis with supply side focus. Submitted to Renewable \& Sustainable Energy Reviews.

Lönnqvist, T., Sanches-Pereira, A., Sandberg, T., 2015. Biogas potential for sustainable transporta Swedish regional case. Journal of Cleaner Production 108, 1105-1114. 
Lönnqvist, T., Silveira, S., Sanches-Pereira, A., 2013. Swedish resource potential from residues and energy crops to enhance biogas generation. Renewable and Sustainable Energy Reviews 21, 298-314. doi:10.1016/j.rser.2012.12.024

Mendu, V., Shearin, T., Campbell, J.E., Stork, J., Jae, J., Crocker, M., Huber, G., DeBolt, S., 2012. Global bioenergy potential from high-lignin agricultural residue. Proceedings of the National Academy of Sciences 109, 4014-4019.

Norell Bergendahl, A., 2016. Den ohållbara resan mot det hållbara resandet: En studie av institutionella förutsättningar för att bedriva planering för hållbart resande i Stockholmsregionen (Licentiate thesis). KTH Royal Institute of Technology.

Nykvist, B., Nilsson, M., 2015. The EV paradox - A multilevel study of why Stockholm is not a leader in electric vehicles. Environmental Innovation and Societal Transitions 14, 26-44. doi:10.1016/j.eist.2014.06.003

Official Inquiry on Fossil Fuel-Free Road Transportation, 2013. Fossil fuel free road transportation (translated) (No. SOU 2013:84). Official Reports of the Swedish Government.

Olsson, L., Hjalmarsson, L., Wikström, M., Larsson, M., 2015. Bridging the implementation gap: Combining backcasting and policy analysis to study renewable energy in urban road transport. Transport Policy 37, 72-82. doi:10.1016/j.tranpol.2014.10.014

Pachauri, R.K., Meyer, L.A.M., and many others, 2014. Climate Change 2014: Synthesis Report. Contribution of Working Groups I, II and III to the Fifth Assessment Report of the Intergovernmental Panel on Climate Change (No. ISBN 978-92-9169-143-2). Intergovernmental Panel on Climate Change (IPCC), Geneva, Switzerland.

Rockström, J., Steffen, W., Noone, K., Persson, A., Chapin, F.S., Lambin, E.F., Lenton, T.M., Scheffer, M., Folke, C., Schellnhuber, H.J., Nykvist, B., de Wit, C.A., Hughes, T., van der Leeuw, S., Rodhe, H., Sörlin, S., Snyder, P.K., Costanza, R., Svedin, U., Falkenmark, M., Karlberg, L., Corell, R.W., Fabry, V.J., Hansen, J., Walker, B., Liverman, D., Richardson, K., Crutzen, P., Foley, J.A., 2009. A safe operating space for humanity. Nature 461, 472 475. doi:10.1038/461472a

Senge, P.M., Scharmer, C.O., Jaworski, J., Flowers, B.S., 2005. Presence: An Exploration of Profound Change in People, Organizations, and Society. Crown Publishing Group.

Statistics Sweden, 2017. Leveranser av fordonsgas [WWW Document]. Statistics Sweden. URL http://www.scb.se/hitta-statistik/statistik-efter-amne/energi/tillforsel-och-anvandningav-energi/leveranser-av-fordonsgas/ (accessed 5.4.17).

Statistics Sweden, 2016. National, county and municipal population number in September 30, 2016 ... (translated) [WWW Document]. Statistiska Centralbyrån. URL http://www.scb.se/hitta-statistik/statistik-efter-amne/befolkning/befolkningenssammansattning/befolkningsstatistik/pong/tabell-och-diagram/kvartals--ochhalvarsstatistik--kommun-lan-och-riket/kvartal-3-2016/ (accessed 1.23.17).

Stockholm County Council., 2017. Environmental declaration 2016. Environmental appendix to the 2016 yearly report from the traffic committee (translated) (No. TN 2015-1526-25TN). Stockholm County Council, Traffic Management Unit.

Svärd, Å., Jansen, J. la C., 2003. Biogas plants in Sweden-compilation of experiences and reporting systems (translated). Stockholm: Svenskt Vatten AB. 
Svensson, M., Baxter, D., and several others, 2015. IEA Bioenergy Task 37 - Country Reports Summary 2015. IEA Bioenergy Task 37.

Swedish cabinet office, 2017. Fact sheet: Proposal referred to the Council on Legislation on a climate policy framework for Sweden.

Swedish Energy Agency, 2016. Transportsektorns energianvändning 2015 (No. ES 2016:03). Statens energimyndighet, Eskilstuna, Sweden.

Swedish Gas Association, Swedish Energy Agency, 2016. Produktion och användning av biogas och rötrester år 2015 (No. ES 2016:04). Swedish Gas Association and The Swedish Energy Agency.

Swedish Waste Management Association, 2012. Sammanställning av resultat från långliggande försök med biogödsel i norden (Rapport No. B2023:03). Avfall Sverige-utveckling, Malmö.

Trist, E.L., 1981. The Evolution of Socio-technical Systems: A Conceptual Framework and an Action Research Program. Ontario Ministry of Labour, Ontario Quality of Working Life Centre.

Upham, P., Klitkou, A., Olsen, D.S., 2016. Using transition management concepts for the evaluation of intersecting policy domains ('grand challenges'): the case of Swedish, Norwegian and UK biofuel policy. International Journal of Foresight and Innovation Policy 11, 73-95.

Vac, S.C., Popita, G.E., others, 2015. Biomass: economical, social and environmental aspects in biogas plants implementation. Journal of Environmental Protection and Ecology 16, 1212-1220.

Vernay, A.-L., Mulder, K.F., Kamp, L.M., de Bruijn, H., 2013. Exploring the socio-technical dynamics of systems integration - the case of sewage gas for transport in Stockholm, Sweden. Journal of Cleaner Production 44, 190-199. doi:10.1016/j.jclepro.2012.11.040

Xylia, M., Silveira, S., 2017. On the road to fossil-free public transport: The case of Swedish bus fleets. Energy Policy 100, 397-412. doi:10.1016/j.enpol.2016.02.024 